Arab World English Journal (AWEJ) 2 ${ }^{\text {nd }}$ Special Issue on Covid 19 Challenges January 2022

DOI: https://dx.doi.org/10.24093/awej/covid2.12

\title{
Exploring the Use of WhatsApp for Teaching Speaking to English Language Learners: A Case Study
}

\author{
Aishah Albogami \\ English Language Center, Taif University, Saudi Arabia \\ Corresponding Author: aqbogamiu@tu.edu.sa
}

\section{Ghazi Algethami}

Foreign Languages Department, Taif University, Saudi Arabia

Received: 9/2/2021 Accepted: $12 / 9 / 2021 \quad$ Published: 1/24/2022

\begin{abstract}
Being able to speak or communicate orally is an ultimate goal for most English language learners. Thus, teaching speaking is a main component of the curriculum in most communicative-based English language classrooms. However, teachers struggle to teach speaking in English language classrooms. Two main reasons contribute to this struggle: insufficient time for speaking practice in language classrooms and students' unwillingness to communicate due to anxiety. Asynchronous Computer-Mediated Communication (ACMC) may have the potential to provide a solution to this difficulty. A widely accessible mobile application that can provide an easily implemented ACMC tool is WhatsApp. The current case study explored the potential use of WhatsApp for teaching English speaking in an English as a Foreign Language (EFL) context. 15 Saudi EFL learners of English were recruited to participate in the present study. A mixed-method approach comprising pre and post-tests, closed-ended questionnaire, and semi-structured interviews were used to collect the data for the current study. The findings showed that using WhatsApp can have the potential for improving EFL learners' speaking performance, increasing their motivation and attitude towards speaking, and decreasing their anxiety and fear of making mistakes when speaking. WhatsApp can provide an effective platform for teaching speaking in an EFL setting where there is a scarcity of time available for oral communication.
\end{abstract}

Keywords: anxiety, attitude, EFL learners, motivation, speaking, WhatsApp

Cite as: Albogami, A., \& Algethami, G. (2022). Exploring the Use of WhatsApp for Teaching Speaking to English Language Learners: A Case Study. Arab World English Journal (AWEJ) $2^{\text {nd }}$ Special Issue on Covid 19 Challenges (2) 183-201.

DOI: https://dx.doi.org/10.24093/awej/covid2.12 
Arab World English Journal (AWEJ) 2nd Special Issue on Covid 19 Challenges January 2022

\section{Introduction}

Speaking proficiency is paramount for successful communication, which is one of the ultimate goals for English language learners. In fact, speaking, amongst the four basic language skills, is the most important for many English language learners (Egan, 1999; Ur, 1996). In addition, language learners are usually evaluated by how well they speak the language (Brown \& Yule, 1983). In spite of its obvious importance, teaching speaking poses a great challenge to many English language teachers, especially in EFL settings (James, 2013; Burns, 2019). Students' anxiety and large classroom size are two of the main challenges encountered by teachers when they teach speaking in EFL classrooms (e.g., Burns, 2019; Hasanah \& Utami, 2019; Wilson, Fang, Rollins \& Valadez, 2016).

The last recent decades have witnessed a huge and growing body of research examining the integration and use of technology in language learning and teaching (Chun, Kern \& Smith, 2016). More recently, with the advent of smartphones, many studies have examined the role which mobile phones could play in enhancing language learning and teaching (Kukulska-Hulme \& Shield, 2008; Demouy \& Kukulska-Hulme, 2010). These studies have shown that mobile technologies can offer innovative solutions to many language teaching obstacles and challenges (Kukulska-Hulme, 2019).

Given that teachers in EFL classrooms face real challenges in teaching speaking due to the unwillingness of students to speak and/or the unavailability of time, using mobile phones, especially in an asynchronous way, to teach speaking can offer a solution to this problem (Chun et al., 2016).

One of the widely used and accessible mobile applications that offer an asynchronous medium of communication is WhatsApp, which is a free social messaging application that allows its users to send and receive written, audio and video messages. A few studies have recently examined the use of WhatsApp voice messaging for enhancing the teaching of speaking in EFL classrooms (Andújar-Vaca \& Cruz-Martínez, 2017; Sherine, Sastry \& Seshagiri, 2020). However, these studies are still small in number and limited to a few EFL contexts. The current study aims to explore the potential of using WhatsApp for teaching and improving Saudi EFL learners' speaking skills. In addition, unlike most previous studies, the current study used a variety of methods to obtain a deeper insight into the use of WhatsApp voice messages in teaching English speaking.

\section{Literature Review}

\section{Speaking Skill Practice in EFL Classrooms}

Being able to speak a foreign language fluently is a goal for which many language learners enroll in EFL courses worldwide (Richards, Richards \& Renandya, 2002). For this reason, language teachers and language institutions should place high importance on speaking inside classrooms, especially in EFL contexts where practice outside classrooms is minimal (Shumin, 2002). However, these classes do not usually provide sufficient time for speaking practice, which is essential for developing speaking proficiency in a foreign language (Grauberg, 1997; Ur, 1996). 
Arab World English Journal (AWEJ) 2nd Special Issue on Covid 19 Challenges January 2022

Speaking a foreign language is a difficult and complex skill (Richards, Richards \& Renandya, 2002). Foreign language learners usually face difficulties when they try to speak (Burns, 2019). Alastuey (2011) pointed out the main factors that lead to this difficulty in foreign language classrooms, which include large number of students in classrooms (Xiao, 2007), teacher-centered teaching methods (Cheon, 2003), and rarity of chances to use the target language outside the classroom (Neri, Mich, Gerosa, \& Giuliani, 2008).

In the context of the current study, Saudi EFL learners have been found to generally exhibit low speaking proficiency level (Soomro \& Farooq, 2018; Aljumah, 2011). A number of factors were found to contribute to this low proficiency level. These factors include inappropriate teaching of speaking in the EFL classroom (e.g., the use of teacher-centered approaches), anxiety of making mistakes while speaking on the part of the learners, inadequate language teaching resources, and insufficient time available for practicing English inside and outside the classroom (Soomro \& Farooq, 2018; Aljumah, 2011). Given the difficulty faced by many language teachers to change much of the practices related to teaching speaking in EFL classrooms, especially in settings where they have little administrative capacity, such as reducing the number of students in classrooms, teachers can employ technology to overcome this difficulty. The need for studies to examine the use of technology for teaching speaking in EFL classrooms is urgent.

\section{Computer-Mediate Communication}

Computer-Mediated Communication (CMC) refers to all types of communication that are conducted using technology or computers (Thurlow, Lengel \& Tomic, 2004; Correa, 2015). There are two main modes of CMC; synchronous and asynchronous. Synchronous CMC refers to the use of computers or technology for communication in real-time (e.g., video conferencing), while asynchronous CMC refers to the use of computers or technology in communicative situations where instantaneous responses are not expected (voice messages). Previous research showed that both modes offer advantages for increasing learners' language proficiency (Alastuey; 2011; Johnson, 2008).

Asynchronous Computer-Mediated Communication (ACMC) has been shown to offer many benefits for language learning and teaching (Gleason \& Suvorov, 2012; Zeiss \& IsabelliGarcía, 2005). ACMC offers a less anxiety-inducing learning environment for learners, provides more time for thinking and language processing, increases learners' confidence and motivation, and provides more opportunities for learners' participation (e.g., AbuSeileek \& Qatawneh, 2013; Chun et al., 2016; Gleason \& Suvorov, 2012; Zeiss \& Isabelli-García, 2005).

A few studies have examined the role of ACMC in enhancing language learners' speaking proficiency. Abrams (2003) studied the effect of using a web-based ACMC tool on learners' oral performance measured in the amount of speech they produced. No advantage was noticed for the group that received instruction using ACMC. James (2013) examined the use of myBrainshark (A web-based ACMC technology) on the oral performance of Spanish learners. The learners were shown to have positive attitudes towards the use of ACMC. Volle (2005) showed that Spanish learners were able to improve their oral proficiency after engaging in synchronous and asynchronous online speaking activities. Hsu (2015) examined the effect of voice blogging as an extracurricular activity on Taiwanese EFL learners' speaking proficiency. The learners' speaking complexity, measured by the number of speech units produced, improved following the activity, 
but no effect was noticed for speaking fluency and accuracy. As shown above, the previous studies that have used ACMC tools to enhance the teaching of speaking to language learners showed conflicting results. This is probably due to the differences in the ACMC tools used and the populations examined. We are not aware of any study that examined the use of ACMC tools for teaching speaking in the Saudi EFL context. We believe that such a study is needed given the many challenges that face the teaching of speaking in the Saudi EFL context.

\section{WhatsApp and Language Teaching}

WhatsApp is a social communication application that is used to exchange text messages, voice calls and messages, videos and pictures. Currently, there are more than two billion users of WhatsApp (https://www.whatsapp.com/about/). In fact, WhatsApp has become an integral part of social communication in Saudi Arabia. The facts that it is free and can be easily uploaded on different smartphone types lead to its attractiveness to many users (Montag et al., 2015). Because of these features, a growing number of studies have examined its potential use for language learning and teaching.

A number of studies have examined the attitudes and perception of language learners towards the use of WhatsApp for enhancing the teaching and learning of foreign languages (Alqahtani, Bhaskar, Elumalai \& Abumelha, 2018; Ali \& Bin-Hady, 2019; Han \& Keskin, 2016; Hamad, 2018). Learners were found to have generally positive attitudes and perception towards the use of WhatsApp.

Two studies have examined the potential use of WhatsApp, as an asynchronous CMC tool, to improve language learners' speaking skill (Andújar-Vaca \& Cruz-Martínez, 2017; Akkara, Anumula \& Mallampalli, 2020). Andújar-Vaca and Cruz-Martínez (2017) used WhatsApp as an extra-curricular activity to teach speaking to Spanish language learners for six months. WhatsApp voices messages were shown to significantly help improve the speaking proficiency of their Spanish learners. Similarly, Akkara et al. (2020) noticed the same effect on the speaking proficiency of their English language learners in rural areas in India.

Given the wide accessibility and use of WhatsApp among students, at least in the EFL Saudi context (Alqahtani et al., 2018), its potential use for enhancing language learning is worth investigating (Kartal, 2019). This is in particular the case for speaking where Saudi EFL learners exhibit low speaking proficiency level (Soomro \& Farooq, 2011) and face many difficulties practicing English in traditional classrooms due to large class sizes and speaking anxiety (AlSeghayer, 2014; Javid, 2013; Soomro \& Farooq, 2011). To the best of our knowledge, we are not aware of any previous study that examined the role of WhatsApp in improving the speaking skill of Saudi EFL learners.

\section{Research Objective}

The current case study aims to explore the potential use of WhatsApp voice messages (WVM, hereafter), as an asynchronous CMC tool, for teaching speaking to EFL Saudi learners.

\section{Method}

The current research used a case study approach to enable the collection of varied date to gain deeper insight into the use of WhatsApp for teaching speaking in the Saudi EFL context. 
The data for the current study were collected from three sources: a small-scale quasiexperimental study, a questionnaire, and semi-structured interviews. The quasi-experiment used a pretest-posttest control group design which restrained most of the extraneous variables that may negatively affect internal validity. This was followed by a questionnaire and semi-structured interviews to explore the learners' perception about the use of WhatsApp for improving their English speaking.

\section{Participants}

Fifteen female undergraduate students from the Foreign Languages Department at Taif University, a public university in Saudi Arabia, voluntarily participated in the current study during the second semester of the academic year 2020. They were homogenous in terms of educational background, age, and gender. They were all female and between the age of 22 and 26. Their first language is Arabic, and they were studying English as a foreign language. The same English instructors teach all the participants. They were studying in their last year at the University.

\section{Teaching Intervention}

The teaching intervention period started in early 2020 and lasted for nine weeks. A WhatsApp group was created by the first author and all the fifteen participants joined immediately. They were requested to voice chat on a topic that would be posted by the first author. During the 9-week duration, a total of 17 topics were posted. The first author, the teacher henceforth, started off the chat by posting the first voice message for each topic. The students were then requested to post a voice message on the topic. They were encouraged to provide more explanation and give more examples on the topic under discussion. They were given the freedom to post the message at any time before the introduction of the next topic. There were not allowed to write in the chat; only voice messaging was allowed. To ensure the participants' full engagement in the task, the first author ran a competition among the participants. At the end of each topic, the teacher announced the winner student who sent the longest voice message and changed the group name into "Congratulations Name of the Winner". The students appeared to like the competition, as was shown in their enthusiasm and active participation. In addition, the teacher was supportive and encouraging so to create a virtual environment conducive to learning. The teacher also provided general feedback to all the students at the end of each topic on their language production without mentioning any specific name or error, as not to create a threatening environment for the students.

\section{Research Instruments}

Three instruments were used to collect the data for the current study: 1) a pre- and postspeaking tests, 2) a questionnaire, and 3) semi-structured interviews.

\section{Pre-/Post-Tests}

Due to the COVID-19 pandemic and the complete closure of universities and schools in Saudi Arabia, we were able to conduct the post-test with only four students. Their speaking performance (pre- post-intervention) was compared to the performance of a control group of four students who were in the same class as the experimental group but did not participate in the WhatsApp teaching intervention experiment. The students in the control group were of the same level and received the same language classes as the students who participated in the intervention 
experiment. Before the national lockdown and the closure of universities, the control group was comprised also of 15 participants, but because we were able to get hold of only four participants from the experimental group in the post-test, we opted to randomly examine only 4 participants from the control group.

A speaking task for measuring the students' speaking skills was adopted from the IELTS exam (International English Language Testing System). To ensure internal validity, the same speaking task (See Appendix A) was administered in both the pre- and post-intervention tests. The pre-test was conducted in person with all the 15 participants in both the experimental and control groups before the closure of universities due to COVID-19. The speaking renditions were recorded, coded and saved into a computer drive. We selected from the pre-test only the recordings of the 4 participants who were able to sit for the post-test, and then randomly contacted 4 participants from the control group to take the post-test for comparison. For the posttest, the 4 participants in each group met with the first author via ZOOM (a web conferencing communication system). As in the pre-test, their speaking was also recorded, coded, and saved into a computer drive. The 16 speaking recordings $(4 * 2$ from the pre-test $\& 4 * 2$ from the posttest) were randomized and then presented to nine experienced English language instructors from the English Language Center at Taif University. They were requested to evaluate all the recordings using the IELTS speaking rubric score (A 9-point scale: $1=$ very low proficiency $-9=$ very high proficiency, See Appendix B).

\section{Questionnaire}

A questionnaire was designed to examine the participants' perspectives on their experience using WVM. Ten statements were adopted with modifications to suit the purpose of the current study from different sources (Ali \& Bin-Hady, 2019; Alqahtani et al., 2018; Cheng \& Kim, 2019; Hamad, 2017; Haque \& Al Salem, 2019) The questionnaire consists of four sections: effectiveness, attitude, motivation, and anxiety. It uses a five-point Likert scale to determine the degree of agreement: 'strongly agree', 'agree', 'neither agree nor disagree', 'disagree', and 'strongly disagree' (see Appendix C). The face validity and suitability of the statements were checked by five associate professors in applied linguistics working at Taif University.

The questionnaire was sent to the 15 participants in the experimental group via WhatsApp after the completion of the intervention. All the students who participated completed the questionnaire online.

\section{Semi-structured Interviews}

The first author conducted one-to-one semi-structured interviews via Zoom with four students from the experimental group after the completion of the treatment. The duration of each interview lasted from 20 to 30 minutes. The questions that led the interviews were:

1. Did using WhatsApp Voice Messages help you speak English? How?

2. What are the things you liked about using WhatsApp Voice Messages to speak English?

3. What difficulties did you face while speaking English using WhatsApp Voice Messages? 
Arab World English Journal (AWEJ) 2nd Special Issue on Covid 19 Challenges January 2022

\section{Results}

\section{The Quasi-experiment}

Table one below shows the mean scores of both groups (the experimental and the control groups) in the pre-and post-intervention speaking tasks.

Table 1. Mean scores and standard deviations for all groups in the pre-and post-intervention tasks

\begin{tabular}{lllc}
\hline Group & Test Type & Mean & Standard Deviation \\
\hline Experimental & Pre-test & 4.00 & .92 \\
Control & Pre-test & 2.84 & .90 \\
Experimental & Post-test & 5.33 & .83 \\
Control & Post-test & 3.62 & .99 \\
\hline
\end{tabular}

Both groups obtained higher scores in the post-test, which indicates that their speaking proficiency have improved regardless of whether they received extra speaking practice via WhatsApp. However, the experimental group showed slightly higher improvement than did the control group. The mean score of the experimental group showed an increase of 1.33 points, while the mean score of the control group showed an increase of 0.78.

Because of the small number of participants in each group, it is worth to examine the mean scores for all the participants in both groups in the pre-and post-tests. Figure one below illustrates the mean speaking scores for each speaker in both groups.

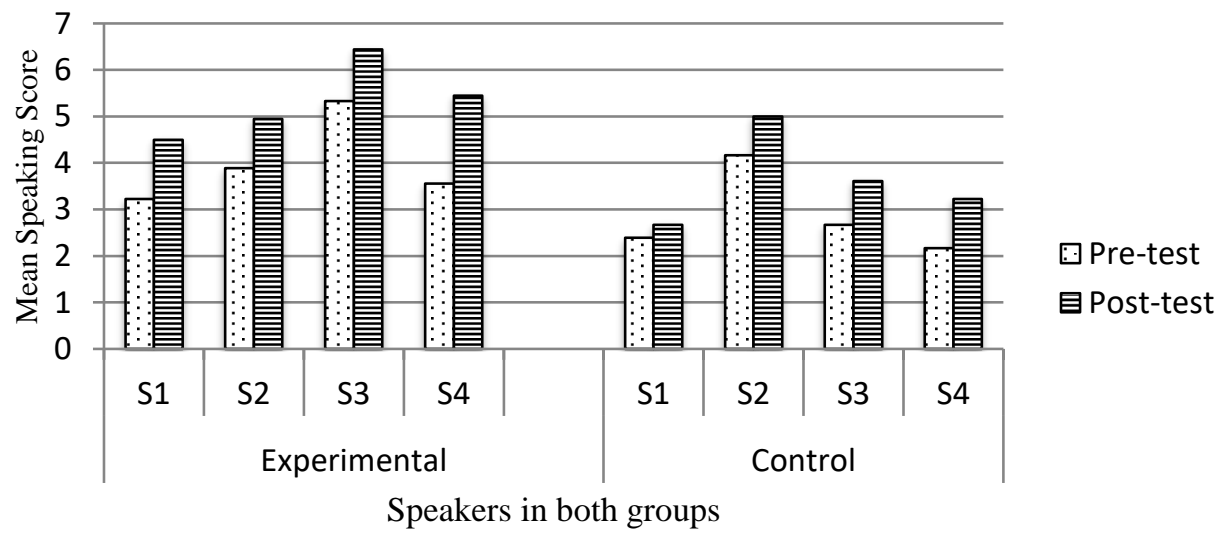

Figure 1. The mean scores for all the participants in both groups on pre and post-tests

All the participants in the experimental group obtained higher speaking scores in the posttest, with participant S4 showing the most improvement. Likewise, all the participants in the control group made some improvement in their speaking scores in the post-test, with S1 making the least improvement.

To summarize, the pre- and post-test results revealed a difference between the experimental group's mean score and the control group's mean score on the post-test in favor of the experimental group. However, both groups improved, and it is not possible to reach any strong conclusion regarding the effect of using WhatsApp unless a larger sample size along with appropriate statistical analysis are used. Because of the small sample size, it was not possible to conduct an inferential statistical analysis. 


\section{The Questionnaire}

Table two illustrates the results for the ten statements of the questionnaire with the percentages of the participants' answers. All the 15 students responded to the questionnaire. The 'strongly agree' responses were conflated with the 'agree' responses and the 'strongly disagree' responses were conflated with the 'disagree' responses.

Table 2. The ten items of the questionnaire and the percentage of the participants' answers

\begin{tabular}{|c|c|c|c|c|}
\hline Section & Statement & Agree & Neutral & Disagree \\
\hline Effectiveness & $\begin{array}{l}\text { English speaking using WVM helped me } \\
\text { improve my speaking skills }\end{array}$ & $93.3 \%$ & $6.6 \%$ & $0 \%$ \\
\hline \multirow[t]{4}{*}{ Attitudes } & English speaking using WVM was easy & $100 \%$ & $0 \%$ & $0 \%$ \\
\hline & $\begin{array}{l}\text { English speaking using WVM was } \\
\text { flexible }\end{array}$ & $93.3 \%$ & $6.6 \%$ & $0 \%$ \\
\hline & $\begin{array}{l}\text { English speaking using WVM was } \\
\text { enjoyable }\end{array}$ & $93.3 \%$ & $6.6 \%$ & $0 \%$ \\
\hline & $\begin{array}{l}\text { Compared to classroom speaking } \\
\text { activities, I prefer using WVM to speak } \\
\text { English }\end{array}$ & $100 \%$ & $0 \%$ & $0 \%$ \\
\hline \multirow[t]{2}{*}{ Motivation } & $\begin{array}{l}\text { I was excited to speak English using } \\
\text { WVM }\end{array}$ & $93.3 \%$ & $6.6 \%$ & $0 \%$ \\
\hline & $\begin{array}{l}\text { Using WVM motivated me to speak } \\
\text { English }\end{array}$ & $100 \%$ & $0 \%$ & $0 \%$ \\
\hline \multirow[t]{3}{*}{ Anxiety } & $\begin{array}{l}\text { Using WVM enhanced my confidence to } \\
\text { speak English }\end{array}$ & $100 \%$ & $0 \%$ & $0 \%$ \\
\hline & $\begin{array}{l}\text { Using WVM helped me overcome my } \\
\text { fear of making mistakes when speaking } \\
\text { English }\end{array}$ & $93.3 \%$ & $6.6 \%$ & $0 \%$ \\
\hline & $\begin{array}{l}\text { I did not get anxious when I was required } \\
\text { to speak English using WVM }\end{array}$ & $93.3 \%$ & $6.6 \%$ & $0 \%$ \\
\hline
\end{tabular}

As can be seen from the above table, the learners clearly had positive opinions towards the use of WVM for practicing speaking. Over $90 \%$ of them agreed that WVM had helped them improve their speaking skills. As for their attitudes towards WVM, most of them agreed that English speaking using WVM was easy, flexible, and enjoyable. Interestingly, all the respondents preferred using WVM to speak in English over speaking activities in the physical classroom.

Regarding their motivation, the participants agreed that they felt motivated and excited to converse in English using WVM. Nearly $94 \%$ of the students felt that WhatsApp had helped them overcome their fear of making mistakes and increase their confidence to speak in English.

In total, four statements received 100\% agreement and the rest received $93.3 \%$ agreement. This means that the feedback on the use of WVM for speaking practice was overwhelmingly positive. The students believed that it had helped them improve their speaking skills, increase their motivation to speak and minimize their speaking anxiety.

\section{The Semi-Structured Interviews}

The interviews' data were recorded, transcribed, coded and classified into five themes: 1) the effects of using WVM on the participants' speaking performance, 2) attitude, 3) motivation, 4) anxiety, and 5) obstacles to using WVM. The results are presented below for each identified theme. 
Arab World English Journal (AWEJ) 2nd Special Issue on Covid 19 Challenges January 2022

\section{The Effect on Speaking Performance}

The interviewees reported that using WVM had a positive impact on improving their speaking proficiency. The following quotation is taken from one of the participants as an example: "when I compared my first voice message to the last one, I really could recognize that I became more fluent when speaking English". Additionally, the students mentioned that they had acquired many new words related to the different topics discussed, as mentioned by Interviewee Three: "in every discussion, I learned many new words." Some also mentioned how the voice messages improved their English pronunciation. For instance, Interviewee Two said: "when I listened to my fellows' voice messages, I noted that I was mispronouncing some words and I began to use an online dictionary to check on my pronunciation". The interviewees believed that using WVM had a positive effect on their productive oral skills. It seems from the students' views that WhatsApp had a positive effect on their fluency, vocabulary, and pronunciation, which are all important components of speaking a foreign language competently. This positive perception on the part of the participants supports the slight improvement of their speaking proficiency found in the small quasi-experimental study.

\section{The Effect on Attitude}

All the interviewees expressed a positive attitude towards using WVM. The following quotation is taken from one of the participants as an example: "I was quite happy to speak in the group because I could practice English speaking in an interesting environment." They also compared their classroom situation where there was hardly time for them to speak to the situation in WhatsApp, where they all had a chance to speak. For instance, one of the interviewees mentioned: "In the classroom, there is not enough time to speak. Our instructors teach us and check the assignments, then the time of the lecture finishes. In contrast, we had sufficient time to think, listen to our colleagues' participation, produce ideas, and finally share ours in the WhatsApp group". Furthermore, an interviewee mentioned her motivation and plans to get a high score in IELTS and to practice speaking using WVM. She said, "I want to get a high score in IELTS and I will use WVM with my friends to speak English." Likewise, Interviewee Four who aspires to be an English instructor said that she would use WVM with her students to improve their speaking skills: "I will use it with my students to help them practice English speaking”. In sum, the participants showed a positive attitude towards using WVM for practicing English speaking.

\section{The Effect on Motivation}

Most of the interviewees reported that using WVM encouraged them to speak English, as illustrated by one of them who said: "When I was listening to my voice messages, I became proud of myself and that inspired me to participate more to show my fluency to my classmates". This quotation reveals how WVM motivated this participant by increasing her confidence and consequently increasing her willingness to communicate and show her speaking ability. The participation of their peers also motivated the students to speak, and this is what was revealed during the interview with one of the participants who said: "Listening to my colleague's participations and how they expressed their ideas encouraged me to speak English and show my speaking skill".

In addition to what they mentioned above, the interviewees also described their enthusiasm while using WVM to speak English. The reason behind this eagerness was expressed by one of 
the respondents who said: "I was in a competition with my colleagues, and I tried to do my best to win". This participant revealed her competitive nature, which explained her strong desire to win and be the best speaker. The creation of a competitive environment and giving a reward for the winner played a considerable role in motivating the students to speak in English. It is difficult though to disentangle the effect of the competition from the effect of WhatsApp on increasing the participants' motivation.

Interviewee Three suggested using videos as a warm-up activity. She said:" Videos will help us listen to various ideas related to each topic so we learn new vocabulary and listen to the correct pronunciation". She felt that using videos to introduce each topic would motivate them and equip them with the vocabulary needed to speak about the topics under discussion.

\section{The Effect on Anxiety}

All the participants during the interviews stated that they were extremely comfortable when practicing English speaking using WVM. For example, Interviewee One explained: "By the third week, I began to overcome my fear of making mistakes". Another student added: "I was speaking slowly, but I began to speak quickly without hesitation". The two participants' quotations revealed that WVM helped them overcome their speaking fear and hesitation. Moreover, one of the respondents made the following observation: "Some do not speak inside the classroom, and they are always silent. I was surprised when I heard them speak in the WhatsApp group. They are good at English speaking". This observation was supported by Interviewee Three, one of the silent ones mentioned by the interviewee above: "I do not speak in the classroom especially when my instructor and colleagues look at me". She continued, "When I was speaking English using WVM, I was speaking freely and comfortably without any interruption, neither from my instructors nor from my colleagues". Moreover, one of the interviewees had this to say: "You can remember when I sent my first voice note to you as a private message and asked you to accept my participation out of the group. But you refused my request. Now, I am very pleased, and I would like to thank you because I could learn from my peers' mistakes and improve my speaking skills". This excerpt shows what one of the participants thought initially that participating in the WhatsApp group would be a burden. However, being in the group gave her the opportunity to listen to her peers, and consequently overcome her fear and share her ideas with more courage. Thus, it can be concluded that the students were not worried about their oral performance using WVM and they were able overcome their fear and speak confidently.

\section{Obstacles}

As expected, due to its user-friendly interface, accessibility and ease of use, all the interviewees reported that they did not face any obstacles while using WVM to practice English speaking. Examples of their statements are: "Actually, I did not face any obstacle when I used WVM" and "Using these audio messages was easy and interesting". In summary, the participants did not face any difficulties while using WVM and they expressed high satisfaction about their experience. They also expressed their strong desire to use WVM in the future so that they can practice speaking English. 


\section{Discussion}

The current study aimed to explore the potential of using WhatsApp, as asynchronous computer-mediated communication tool, to enhance the learning and teaching of English speaking skill. It used a case-study, mixed method approach to gain deep insight into the use of WhatsApp for teaching and learning speaking.

The result of the quasi-experimental study showed some improvement in the speaking performance of both the experimental and control groups. The experimental group showed, on average, higher improvement than did the control group. The scores of the individual participants in both groups showed high variation, which clearly indicates the need to use larger sample size to reach any conclusive finding regarding the use of WVM for improving the speaking skill of EFL learners. Nonetheless, the finding is consistent with that of Andújar-Vaca and CruzMartínez (2017) and Akkara et. al (2020) which found that the use of WhatsApp was effective in improving the speaking skill of the participants in their studies. More studies are needed to lend further credence to the effectiveness of WhatsApp for enhancing EFL learners' speaking skill.

Similar to Hamad (2017), the results of the questionnaire and interviews indicate that the students found WVM helpful for improving their speaking skill. The students also held positive attitudes and opinions towards WVM regarding its use and its contribution to increasing their motivation and confidence and reducing their anxiety. However, for motivation, we are not sure whether it was the result of the application itself or the competitive environment that was created by the teacher. The students found the application for speaking practice easy to use, flexible, and enjoyable and thought that it was even better for speaking practice than traditional face-to-face classes. These findings are in line with previous research. Both Ali and Bin-Hady (2019) and Almogheerah (2020) showed that students had positive attitudes towards the use of WhatsApp for language learning. Alqahtani et al. (2018) showed that their participants were motivated to use WhatsApp to speak in English. Han and Keskin (2016) and Hamad (2017) showed that the use of WhatsApp for language learning significantly lowered the level of their participants' anxiety and fear of speaking.

\section{Conclusion}

The results of the current study clearly indicate the potential of WhatsApp, as a widely accessible and easy to use ACMC tool, to enhance the teaching of speaking to EFL learners. It was found to increase the motivation and reduce the anxiety of EFL learners to practice speaking. However, it is difficult to draw any strong conclusion regarding the actual effectiveness of the application, as the current study examined only its impact on the speaking performance of a small number of students. Further research should examine its effect on a larger sample size.

Interested teachers are recommended to try using WVM for conducting speaking extracurricular activities for their students. This is in particular the case for classes with large number of students, where there is no chance for all students to speak. We assume that the same advantages found in using WhatsApp can be extended to all ACMC tools, such as other social network applications; however, this may need further investigation because of the design and interface variation among applications. 
Arab World English Journal (AWEJ) 2nd Special Issue on Covid 19 Challenges January 2022

About the authors:

Aishah Albogami is an English language instructor at Taif University English Language Center.

She has a Master's degree in Linguistics. She is interested in the field of teaching English as a Foreign Language. https://orcid.org/0000-0002-7777-8940

Ghazi Algethami is an Associate Professor in Linguistics at Taif University. He is interested in second/foreign language speech. In particular, he is interested in how second/foreign language speech is perceived and produced, and what are the factors that may affect learners' learning of second/foreign language speech (e.g., language use and pronunciation instruction). https://orcid.org/0000-0003-0575-9529

\section{References}

Abrams, Z. (2003). The effect of synchronous and asynchronous CMC on oral performance in German. The Modern Language Journal, 87(2), 157-167. https://doi.org/10.1111/15404781.00184

AbuSeileek, A. F., \& Qatawneh, K. (2013). Effects of synchronous and asynchronous computer-mediated communication (CMC) oral conversations on English language learners' discourse functions. Computers \& Education, 62, 181-190. https://doi.org/10.1016/j.compedu.2012.10.013

Akkara, S., Mallampalli, M. \& Anumula, V. (2020). Improving second language speaking and pronunciation through smartphones. International Journal of Interactive Mobile Technologies, 14(11), 280-287.

Alastuey, B. (2011). Perceived benefits and drawbacks of synchronous voice-based computermediated communication in the foreign language classroom. Computer Assisted Language Learning, 24(5), 419-432. https://doi.org/10.1080/09588221.2011.574639

Ali, J. \& Bin-Hady, W. (2019). A study of EFL students' attitudes, motivation and anxiety towards WhatsApp as a language learning tool. Arab World English Journal: Special Issue on CALL Number, 5, 289-298. https://dx.doi.org/10.24093/awej/call5.19

Aljumah, F. (2011). Developing Saudi EEF Students' Oral Skills: An Integrative Approach. English Language Teaching, 4(3), 84-89.

Al-Seghayer, K. (2014). The four most common constraints affecting English teaching in Saudi Arabia. International Journal of English Linguistics, 4(5), 17-26.

Almogheerah, A. (2021). Exploring the Effect of Using WhatsApp on Saudi Female EFL Students' Idiom-Learning. Arab World English Journal, 11(4), 328-350. https://dx.doi.org/10.24093/awej/vol11no4.22

Alqahtani, M., Bhaskar, C., Vadakalur Elumalai, K., \& Abumelha, M. (2018). WhatsApp: An online platform for university-level English language education. Arab World English Journal, 9 (4), 108-121. https://dx.doi.org/10.24093/awej/vol9no4.7

Andújar-Vaca, A., \& Cruz-Martínez, M.-S. (2017). Mobile instant messaging: WhatsApp and its potential to develop oral skills. Comunicar: Media Education Research Journal, 25(1), 43-52. https://doi.org/10.3916/C50-2017-04

Burns, A. (2019). Concepts for teaching speaking in the English language classroom. LEARN Journal: Language Education and Acquisition Research Network, 12(1), 1-11.

Cheng, J., \& Kim, H.-J. (2019). Attitudes towards English Language Learning Apps from Korean and Chinese EFL Student. English Teaching, 74(4), 205-224. 
Arab World English Journal (AWEJ) 2nd Special Issue on Covid 19 Challenges January 2022

Cheon, H. (2003). The viability of computer mediated communication in the Korean secondary EFL classroom. Asian EFL Journal, 5, 1-61.

Chun, D., Kern, R., \& Smith, B. (2016). Technology in language use, language teaching, and language learning. The Modern Language Journal, 100, 64-80. https://doi.org/10.1111/modl.12302

Demouy, V., \& Kukulska-Hulme, A. (2010). On the spot: Using mobile devices for listening and speaking practice on a French language programme. Open Learning: The Journal of Open, Distance and e-Learning, 25(3), 217-232. https://doi.org/10.1080/02680513.2010.511955

Egan, K. (1999). Speaking: A critical skill and a challenge. Calico Journal, 16(3) 277-293.

Grauberg, W. (1997). The elements of foreign language teaching (Vol. 7). Multilingual Matters. Gillian, B., \& Yule, G. (1983). Teaching the spoken language. Cambridge University Press.

Gleason, J., \& Suvorov, R. (2012). Learner perceptions of asynchronous oral computermediated communication: Proficiency and second langauge selves. Canadian Journal of Applied Linguistics, 15(1), 100-121.

Hamad, M. (2017). Using WhatsApp to Enhance Students' Learning of English Language" Experience to Share. Higher Education Studies, 7(4), 74-87.

Han, T., \& Keskin, F. (2016). Using a mobile application (WhatsApp) to reduce EFL speaking anxiety. Gist: Education and Learning Research Journal, 12, 29-50. https://doi.org/10.26817/16925777.243

Haque, S., \& Al Salem, N. (2019). Social Media in EFL Context: Attitudes of Saudi Learners. Journal of Language Teaching and Research, 10(5), 1029-1040.

Hasanah, N., \& Utami, P. (2019). Emerging Challenges of Teaching English in Non-Native English-Speaking Countries: Teachers' View. English Language Teaching Educational Journal, 2(3), 112-120.

Hsu, H.-C. (2016). Voice blogging and L2 speaking performance. Computer Assisted Language Learning, 29(5), 968-983. https://doi.org/10.1080/09588221.2015.1113185

James, N. P. (2013). Exploring the benefits of ACMC for speaking development. IALLT Journal of Language Learning Technologies, 43(1), 25-63. https://doi.org/10.17161/iallt.v43i1.8517

Javid, C. (2014). Measuring language anxiety in an EFL context. Journal of Education and Practice, 5(25), 180-193.

Johnson, G. (2008). The relative learning benefits of synchronous and asynchronous text based discussion. British Journal of Information Technology, 39, 166-169.

Kartal, G. (2019). What's up with WhatsApp? A critical analysis of mobile instant messaging research in language learning. International Journal of Contemporary Educational Research, 6(2), 352-365.

Kukulska-Hulme, A. (2019). Mobile Language Learning Innovation Inspired by Migrants. Journal of Learning for Development, 6(2), 116-129.

Kukulska-Hulme, A., \& Shield, L. (2008). An overview of mobile assisted language learning: From content delivery to supported collaboration and interaction. ReCALL, 20(3), 271289. https://doi.org/10.1017/S0958344008000335

Montag, Błaszkiewicz, Sariyska, Lachmann, Andone, Trendafilov, Eibes \& Markowetz. (2015). Smartphone usage in the 21st century: who is active on WhatsApp? BMC research notes, 8(1), 1-6. https://doi: 10.1186/s13104-015-1280-z 
Arab World English Journal (AWEJ) 2nd Special Issue on Covid 19 Challenges January 2022

Neri, A., Mich, O., Gerosa, M., \& Giuliani, D. (2008). The effectiveness of computer assisted pronunciation training for foreign language learning by children. Computer Assisted Language Learning, 21, 393-408. https://doi.org/10.1080/09588220802447651

Richards, J., Richards, J., \& Renandya, W. (2002). Methodology in language teaching: An anthology of current practice: Cambridge university press.

Shumin, K. (2002). Factors to consider: Developing adult EFL students' speaking abilities. In J. Richards, J. Richards \& W. Renandya (Eds.), Methodology in language teaching: An anthology of current practice (Vol. 12, pp. 204-211). Cambridge University Press.

Soomro, A. F., \& Farooq, M. U. (2018). EFL learners' attitude towards developing speaking skills at the University of Taif, Saudi Arabia. International Journal of English Linguistics, 8(3), 318-327.

Ur, P. (1996). A course in language teaching: Practice and theory. Ernst Klett Sprachen.

Volle, L. (2005). Analyzing oral skills in voice e-mail and online interviews. Language Learning \& Technology, 9(3), 146-163. http://dx.doi.org/10125/44036

Xiao, J. (2007). Language learning strategies in distance English learning: A study of learners at Shantou Radio and Television University, China. Journal of Asia TEFL, 4(2), 141-164.

Wilson, J., Fang, C., Rollins, J., \& Valadez, D. (2016). An Urgent Challenge: Enhancing Academic Speaking Opportunities for English Learners. Multicultural Education, 23(2), 52-54.

Zeiss, E., \& Isabelli-García, C. (2005). The role of asynchronous computer mediated communication on enhancing cultural awareness. Computer Assisted Language Learning, 18(3), 151-169. https://doi.org/10.1080/09588220500173310

\section{Appendices}

Appendix A: IELTS Speaking Test

British Council (n.d). IELTS practice Speaking test - part 1. Retrieved from https://takeielts.britishcouncil.org/take-ielts/prepare/free-ielts-practice-tests/speaking/part-1

\section{Part 1:}

Let's talk about your hometown or village.

What kind of place is it?

What's the most interesting part of your town/village?

What kind of jobs do the people in your town/village do?

Would you say it's a good place to live? (Why?)

Let's move on to talk about accommodation.

Tell me about the kind of accommodation you live in?

How long have you lived there?

What do you like about living there?

What sort of accommodation would you most like to live in?

\section{Part 2:}

Candidate Task Card.

Describe something you own which is very important to you.
You should say:
where you got it from
how long you have it
what you use it for


Arab World English Journal (AWEJ) 2nd Special Issue on Covid 19 Challenges January 2022

and explain why it is so important to you.

[You will have to talk about the topic for 1 to 2 minutes. You have one minute to think about what you're going to say. You can make some notes to help you if you wish.]

\section{Rounding off questions}

\section{Tell me:}

Is it valuable in terms of money?

Would it be easy to replace?

\section{Part 3:}

Let's consider first of all how people's values have changed.

What kinds of things give status to people in your country?

Have things changed since your parents' time?

Finally, let's talk about the role of advertising.

Do you think advertising influences what people buy?

Appendix B: IELTS Scoring Rubric

IELTS (n.d). IELTS Scoring Rubric. Retrieved from www.ielts.org 
Arab World English Journal (AWEJ) 2nd Special Issue on Covid 19 Challenges January 2022

Exploring the Use of WhatsApp for Teaching Speaking

Albogami \& Algethami

\begin{tabular}{|c|c|c|c|c|}
\hline Band & Pronunciation & $\begin{array}{l}\text { Grammatical range } \\
\text { and accuracy }\end{array}$ & Lexical resource & $\begin{array}{l}\text { Fluency and } \\
\text { coherence }\end{array}$ \\
\hline 9 & $\begin{array}{l}\text {-uses a full range } \\
\text { of pronunciation } \\
\text { features with } \\
\text { precision and } \\
\text { subtlety } \\
\text {-sustains flexible } \\
\text { use of features } \\
\text { throughout } \\
\text {-is effortless to } \\
\text { understand }\end{array}$ & $\begin{array}{l}\text {-uses a full range of } \\
\text { structures naturally } \\
\text { and appropriately } \\
\text { •produces consistently } \\
\text { accurate structures } \\
\text { apart from 'slips' } \\
\text { characteristic of native } \\
\text { speaker speech }\end{array}$ & $\begin{array}{l}\text {-uses vocabulary } \\
\text { with full flexibility } \\
\text { and precision in all } \\
\text { topics } \\
\text { •uses idiomatic } \\
\text { language naturally } \\
\text { and accurately }\end{array}$ & $\begin{array}{l}\text {-speaks } \\
\text { fluently with } \\
\text { only rare } \\
\text { repetition or } \\
\text { self- } \\
\text { correction; } \\
\text {-any } \\
\text { hesitation is } \\
\text { content- } \\
\text { related rather } \\
\text { than to find } \\
\text { words or } \\
\text { grammar } \\
\text {-speaks } \\
\text { coherently } \\
\text { with fully } \\
\text { appropriate } \\
\text { cohesive } \\
\text { features } \\
\text { •develops } \\
\text { topics fully } \\
\text { and } \\
\text { appropriately }\end{array}$ \\
\hline 8 & $\begin{array}{l}\text { •uses a wide } \\
\text { range of } \\
\text { pronunciation } \\
\text { features } \\
\text {-sustains flexible } \\
\text { use of features, } \\
\text { with only } \\
\text { occasional lapses } \\
\text { •is easy to } \\
\text { understand } \\
\text { throughout; L1 } \\
\text { accent has } \\
\text { minimal effect } \\
\text { on intelligibility }\end{array}$ & $\begin{array}{l}\text {-uses a wide range of } \\
\text { structures flexibly } \\
\text {-produces a majority } \\
\text { of error-free sentences } \\
\text { with only very } \\
\text { occasional } \\
\text { inappropriacies or } \\
\text { basic/non-systematic } \\
\text { errors }\end{array}$ & $\begin{array}{l}\text { •uses a wide } \\
\text { vocabulary } \\
\text { resource readily } \\
\text { and flexibly to } \\
\text { convey precise } \\
\text { meaning } \\
\text { •uses less common } \\
\text { and idiomatic } \\
\text { vocabulary } \\
\text { skilfully, with } \\
\text { occasional } \\
\text { inaccuracies } \\
\text { •uses paraphrase } \\
\text { effectively as } \\
\text { required }\end{array}$ & $\begin{array}{l}\text {-speaks } \\
\text { fluently with } \\
\text { only } \\
\text { occasional } \\
\text { repetition or } \\
\text { self- } \\
\text { correction; } \\
\text { hesitation is } \\
\text { usually } \\
\text { content- } \\
\text { related and } \\
\text { only rarely to } \\
\text { search for } \\
\text { language } \\
\text {-develops } \\
\text { topics } \\
\text { coherently } \\
\text { and } \\
\text { appropriately }\end{array}$ \\
\hline 7 & $\begin{array}{l}\text {-shows all the } \\
\text { positive features } \\
\text { of Band } 6 \text { and } \\
\text { some, but not all, } \\
\text { of the positive } \\
\text { features of Band } \\
8\end{array}$ & $\begin{array}{l}\text {-uses a range of } \\
\text { complex structures } \\
\text { with some flexibility } \\
\text {-frequently produces } \\
\text { error-free sentences, } \\
\text { though some } \\
\text { grammatical mistakes } \\
\text { persist }\end{array}$ & $\begin{array}{l}\text {-uses vocabulary } \\
\text { resource flexibly } \\
\text { to discuss a variety } \\
\text { of topics } \\
\text {-uses some less } \\
\text { common and } \\
\text { idiomatic } \\
\text { vocabulary and } \\
\text { shows some }\end{array}$ & $\begin{array}{l}\cdot \text { speaks at } \\
\text { length } \\
\text { without } \\
\text { noticeable } \\
\text { effort or loss } \\
\text { of coherence } \\
\text {-may } \\
\text { demonstrate } \\
\text { language- }\end{array}$ \\
\hline Arab & English Journal & & \multicolumn{2}{|c|}{\begin{tabular}{l|l} 
awareness of style & related \\
and collocation, & 198 ww.aptorg \\
hesitation at
\end{tabular}} \\
\hline
\end{tabular}




\begin{tabular}{|c|c|c|c|c|}
\hline & & & $\begin{array}{l}\text { with some } \\
\text { inappropriate } \\
\text { choices } \\
\text { •uses paraphrase } \\
\text { effectively }\end{array}$ & $\begin{array}{l}\text { times, or } \\
\text { some } \\
\text { repetition } \\
\text { and/or self- } \\
\text { correction } \\
\text { •uses a range } \\
\text { of } \\
\text { connectives } \\
\text { and discourse } \\
\text { markers with } \\
\text { some } \\
\text { flexibility }\end{array}$ \\
\hline 6 & $\begin{array}{l}\text { •uses a range of } \\
\text { pronunciation } \\
\text { features with } \\
\text { mixed control } \\
\text { •shows some } \\
\text { effective use of } \\
\text { features but this } \\
\text { is not sustained } \\
\text { •can generally be } \\
\text { understood } \\
\text { throughout, } \\
\text { though } \\
\text { mispronunciation } \\
\text { of individual } \\
\text { words or sounds } \\
\text { reduces clarity at } \\
\text { times }\end{array}$ & $\begin{array}{l}\text {-uses a mix of simple } \\
\text { and complex } \\
\text { structures, but with } \\
\text { limited flexibility } \\
\text { •may make frequent } \\
\text { mistakes with } \\
\text { complex structures } \\
\text { though these rarely } \\
\text { cause comprehension } \\
\text { problems }\end{array}$ & $\begin{array}{l}\text {-has a wide } \\
\text { enough vocabulary } \\
\text { to discuss topics at } \\
\text { length and make } \\
\text { meaning clear in } \\
\text { spite of } \\
\text { inappropriacies } \\
\text {-generally } \\
\text { paraphrases } \\
\text { successfully }\end{array}$ & $\begin{array}{l}\text {-is willing to } \\
\text { speak at } \\
\text { length, } \\
\text { though may } \\
\text { lose } \\
\text { coherence at } \\
\text { times due to } \\
\text { occasional } \\
\text { repetition, } \\
\text { self- } \\
\text { correction or } \\
\text { hesitation } \\
\text { •uses a range } \\
\text { of } \\
\text { connectives } \\
\text { and discourse } \\
\text { markers but } \\
\text { not always } \\
\text { appropriately }\end{array}$ \\
\hline 5 & $\begin{array}{l}\text {-shows all the } \\
\text { positive features } \\
\text { of Band } 4 \text { and } \\
\text { some, but not all, } \\
\text { of the positive } \\
\text { features of Band } \\
6\end{array}$ & $\begin{array}{l}\text { •produces basic } \\
\text { sentence forms with } \\
\text { reasonable accuracy } \\
\text { •uses a limited range } \\
\text { of more complex } \\
\text { structures, but these } \\
\text { usually contain errors } \\
\text { and may cause some } \\
\text { comprehension } \\
\text { problems }\end{array}$ & $\begin{array}{l}\text {-manages to talk } \\
\text { about familiar and } \\
\text { unfamiliar topics } \\
\text { but uses } \\
\text { vocabulary with } \\
\text { limited flexibility } \\
\text {-attempts to use } \\
\text { paraphrase but } \\
\text { with mixed } \\
\text { success }\end{array}$ & $\begin{array}{l}\text { •usually } \\
\text { maintains } \\
\text { flow of } \\
\text { speech but } \\
\text { uses } \\
\text { repetition, } \\
\text { self } \\
\text { correction } \\
\text { and/or slow } \\
\text { speech to } \\
\text { keep going } \\
\text { •may over- } \\
\text { use certain } \\
\text { connectives } \\
\text { and discourse } \\
\text { markers } \\
\text { •produces } \\
\text { simple } \\
\text { speech } \\
\text { fluently, but } \\
\text { more } \\
\text { complex } \\
\text { communicati } \\
\text { on causes }\end{array}$ \\
\hline
\end{tabular}


Arab World English Journal (AWEJ) 2nd Special Issue on Covid 19 Challenges January 2022

\begin{tabular}{|c|c|c|c|c|}
\hline & & & & $\begin{array}{l}\text { fluency } \\
\text { problems }\end{array}$ \\
\hline 4 & $\begin{array}{l}\text {-uses a limited } \\
\text { range of } \\
\text { pronunciation } \\
\text { features } \\
\text { •attempts to } \\
\text { control features } \\
\text { but lapses are } \\
\text { frequent } \\
\text { •mispronunciatio } \\
\text { ns are frequent } \\
\text { and cause some } \\
\text { difficulty for the } \\
\text { listener }\end{array}$ & $\begin{array}{l}\text {-produces basic } \\
\text { sentence forms and } \\
\text { some correct simple } \\
\text { sentences but } \\
\text { subordinate structures } \\
\text { are rare } \\
\text { •errors are frequent } \\
\text { and may lead to } \\
\text { misunderstanding }\end{array}$ & $\begin{array}{l}\text {-is able to talk } \\
\text { about familiar } \\
\text { topics but can only } \\
\text { convey basic } \\
\text { meaning on } \\
\text { unfamiliar topics } \\
\text { and makes } \\
\text { frequent errors in } \\
\text { word choice } \\
\text {-rarely attempts } \\
\text { paraphrase }\end{array}$ & $\begin{array}{l}\text { •cannot } \\
\text { respond } \\
\text { without } \\
\text { noticeable } \\
\text { pauses and } \\
\text { may speak } \\
\text { slowly, with } \\
\text { frequent } \\
\text { repetition and } \\
\text { self- } \\
\text { correction } \\
\text { - links basic } \\
\text { sentences but } \\
\text { with } \\
\text { repetitious } \\
\text { use of simple } \\
\text { connectives } \\
\text { and some } \\
\text { breakdowns } \\
\text { in coherence }\end{array}$ \\
\hline 3 & $\begin{array}{l}\text {-shows some of } \\
\text { the features of } \\
\text { Band } 2 \text { and } \\
\text { some, but not all, } \\
\text { of the positive } \\
\text { features of Band } \\
4\end{array}$ & $\begin{array}{l}\text {-attempts basic } \\
\text { sentence forms but } \\
\text { with limited success, } \\
\text { or relies on apparently } \\
\text { memorised utterances } \\
\text { •makes numerous } \\
\text { errors except in } \\
\text { memorised } \\
\text { expressions }\end{array}$ & $\begin{array}{l}\text {-uses simple } \\
\text { vocabulary to } \\
\text { convey personal } \\
\text { information } \\
\text { •has insufficient } \\
\text { vocabulary for less } \\
\text { familiar topics }\end{array}$ & $\begin{array}{l}\text {-speaks with } \\
\text { long pauses } \\
\text { • has limited } \\
\text { ability to link } \\
\text { simple } \\
\text { sentences } \\
\text { - gives only } \\
\text { simple } \\
\text { responses and } \\
\text { is frequently } \\
\text { unable to } \\
\text { convey basic } \\
\text { message }\end{array}$ \\
\hline 2 & $\begin{array}{l}\text {-Speech is often } \\
\text { unintelligible }\end{array}$ & $\begin{array}{l}\text {-cannot produce basic } \\
\text { sentence forms }\end{array}$ & $\begin{array}{l}\text {-only produces } \\
\text { isolated words or } \\
\text { memorised } \\
\text { utterances }\end{array}$ & $\begin{array}{l}\text {-pauses } \\
\text { lengthily } \\
\text { before most } \\
\text { words } \\
\text {-little } \\
\text { communicati } \\
\text { on possible } \\
\end{array}$ \\
\hline 1 & $\begin{array}{l}\bullet \text { no } \\
\text { communication } \\
\text { possible } \\
\bullet \text { no rateable } \\
\text { language }\end{array}$ & & & \\
\hline 0 & -does not attend & & & \\
\hline
\end{tabular}

Appendix C: The Questionnaire

\begin{tabular}{|l|l|l|l|l|l|l|l|}
\hline Section & No. & Statement & SA A & D & SD \\
\hline Effectiveness & 1 & $\begin{array}{l}\text { English speaking using WVM helped me improve my } \\
\text { speaking skills }\end{array}$ & & & & \\
\hline \hline
\end{tabular}


Arab World English Journal (AWEJ) 2nd Special Issue on Covid 19 Challenges January 2022

Exploring the Use of WhatsApp for Teaching Speaking

Albogami \& Algethami

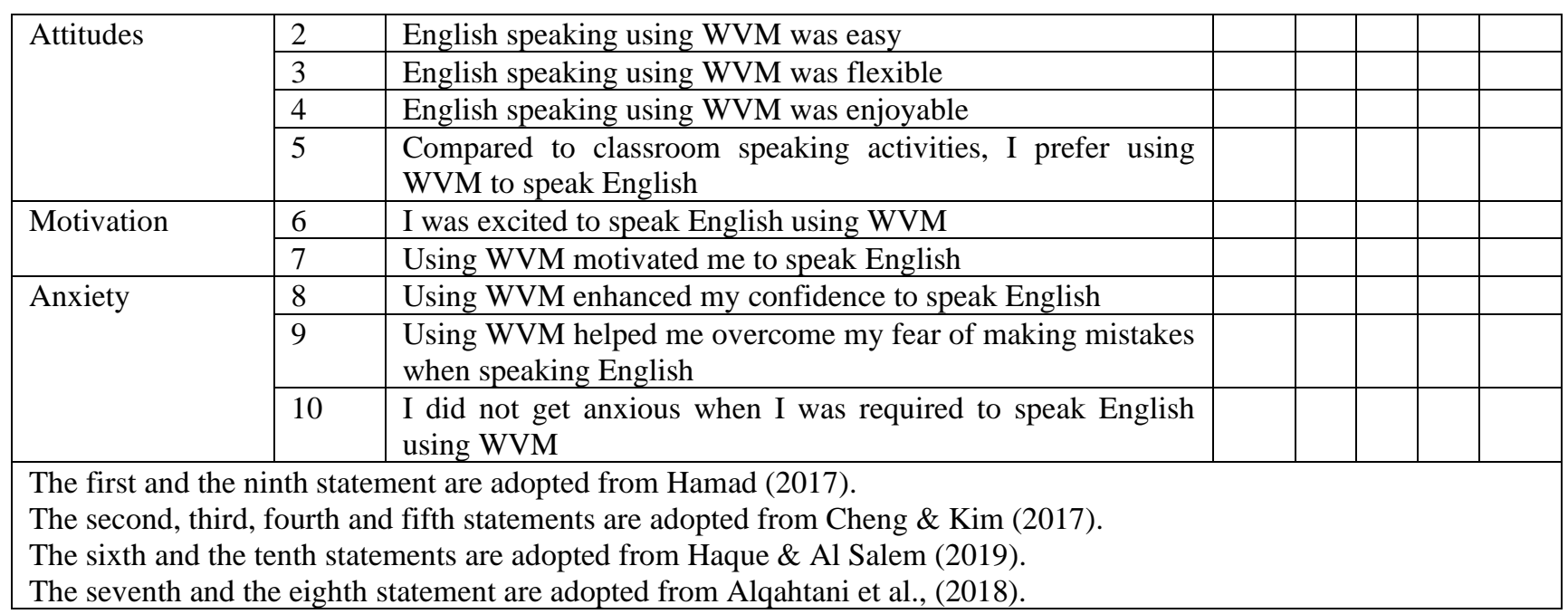

